Contents lists available at Џournal IICET

International Journal of Technology, Innovation and

Humanities

ISSN: 2746-6434 (Electronic)

\title{
Welch powell algoritma aplication to identify the conflict of lesson timetable (case study: informatics engineering, stikom yos sudarso Purwokerto)
}

\author{
Diandra Chika Fransisca ${ }^{1}$, Safar Dwi Kurniawan ${ }^{1}$ \\ ${ }^{1}$ Departement of Informatics Engineering, Sekolah Tinggi Ilmu Komputer Yos Sudarso, \\ Purwokerto, Indonesia
}

\section{Article Info \\ Article history: \\ Received Sep 12th, 2020 \\ Revised Oct 17th, 2020 \\ Accepted Oct 24th, 2020}

\section{Keyword:}

Graph

academic systems

welch powell

scheduling

point coloring

\begin{abstract}
The lecture timetable is a requirement which done each semester by an academic system department in a university. The academic system department faces lecture schedule conflict while they are making it. Welsh Powell algorithm is one of graph theory which can be a solution for the academic system department in a university to avoid the conflict. Accordingly, the purpose of the research is to apply the Welch Powell algorithm for detecting lecture schedule conflict in Informatics Engineering major in STIKOM Yos Sudarso in even semester. The researcher uses two stages of the research method in this study: to collect the data and to implement the model. This research collects the needed data from Informatics Engineering students who take the lecture in even semester. While in the implementation, the researcher collects the model data afterward processed with the Welch Powell algorithm. The conclusion of this research is the Welch Powell algorithm is effective to avoid the conflict of the lesson timetable. The algorithm produces chromatic number 8 . It means using the Welch Powell algorithm has 8 conditions course scheduling which can be set so that the conflict does not happen.
\end{abstract}

(C) 2020 The Authors. Published by IICET.

This is an open access article under the CC BY-NC-SA license

(https://creativecommons.org/licenses/by-nc-sa/4.0

\section{Corresponding Author:}

Diandra Chika Fransisca,

Departement of Informatics Engineering, Institut Teknologi Telkom Purwokerto, Indonesia

Email: diandrachika10181993@gmail.com

\section{Introduction}

A course scheduling is a requirement in each semester made by an academic system department of a university. The academic system department faces a problem while they are making a schedule, the problem is schedule conflict which crashes with other courses. Basically, in arranging the course schedule, it must be suitable in such a way there will be no schedule conflict so students can get the lecture which they need without any schedule conflict/course crash. Some factors that cause the conflict are the students who take many courses, the number of courses is getting more, the time is limit, because of limited of lectures and the classroom use for studying is limit. As a result, the student who takes many lectures will face the schedule conflict. One of graph theory can show the problem of lecture conflict is graph coloring with Welch Powell algorithm. 
Welch Powell algorithm is one of the graph coloring algorithms which does coloring based on the highest degree of the knots (Maryana, 2015) (Handayani, Ely and Paramita, 2016). This algorithm can be used to color a graph efficiently to avoid schedule conflict in a place (Jaya, 2019). In other words, Welch Powell can be a solution for the academic system in a university to avoid the conflict (Astuti, 2011).

Institute of Computer Science (STIKOM) Yos Sudarso is one of the private university in Purwokerto which has an Informatics Engineering program. This major was established on September 15th, 2015. It means the oldest batch in Informatics Engineering program is the 8th semester. Because the Informatics Engineering program is still new therefore STIKOM Yos Sudarso deals with a course scheduling conflict although the academic system department has finished arranging it. Yet the fact, the university makes the schedule still manually. An effect from this matter, the schedule isn't efficient and effective because it can changeable. Accordingly, course scheduling needs a course scheduling system in order to one course with others who don't crash each other. Based on the description, the researcher is interested to apply the Welch Powell algorithm for detecting course scheduling conflict (course scheduling study case in Informatics Engineering major, STIKOM Yos Sudarso).

\section{Method}

The researcher does 2 stages are: (1) Collecting the data and (2) Model implementation. Picture 3 displays a flowchart from the research methodology will be used.

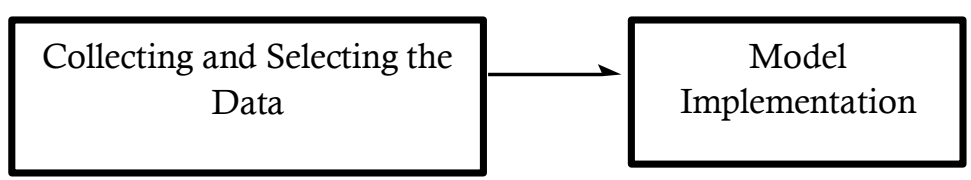

Figure $1<$ Research Methodology $>$

\section{Collecting and Selecting The Data}

The researcher takes course data of the Informatics Engineering study program STIKOM Yos Sudarso. The researcher uses the data for this research consist of the name of the course and the students' name who takes the course each batch. Number 1 shows the students who take the course and 0 shows the students who don't take the course.

\section{Model Implementation}

Students' variety who take the course is shown in vertex displayed mathematically in a graph. The course is symbolized in the graph in the form of knot is constraint will be filled (Astuti, 2011). A constraint is the number of students who have taken the course in the Informatics Engineering study program where the same color can be put in the same class. Side connects one vertex to others show the students choose the same time with other courses which has vertex alongside with it.

\section{Results and Discussion}

In this part, the researcher will discuss Welch Powell Application to detect course scheduling conflict in the Informatics Engineering study program, STIKOM Yos Sudarso of Purwokerto.

\section{Collecting and Selecting The Data}

In this research, the researcher uses the data from the Informatics Engineering students of $2019-2017$ batch that take courses in even semester. The data of the students of the 2016 batch do not participate in this research because they take the final course which means their schedule is flexible.

\section{Model Implementation}

The simple picture as a model for the Informatics Engineering students who take the course in even semester, the researcher can know which course is taken by the students.

The first step to model the students who take the course with the Welch Powell algorithm is to make knots. The knots as the name of the course. Based on the observation, there are twenty courses that are taken. 


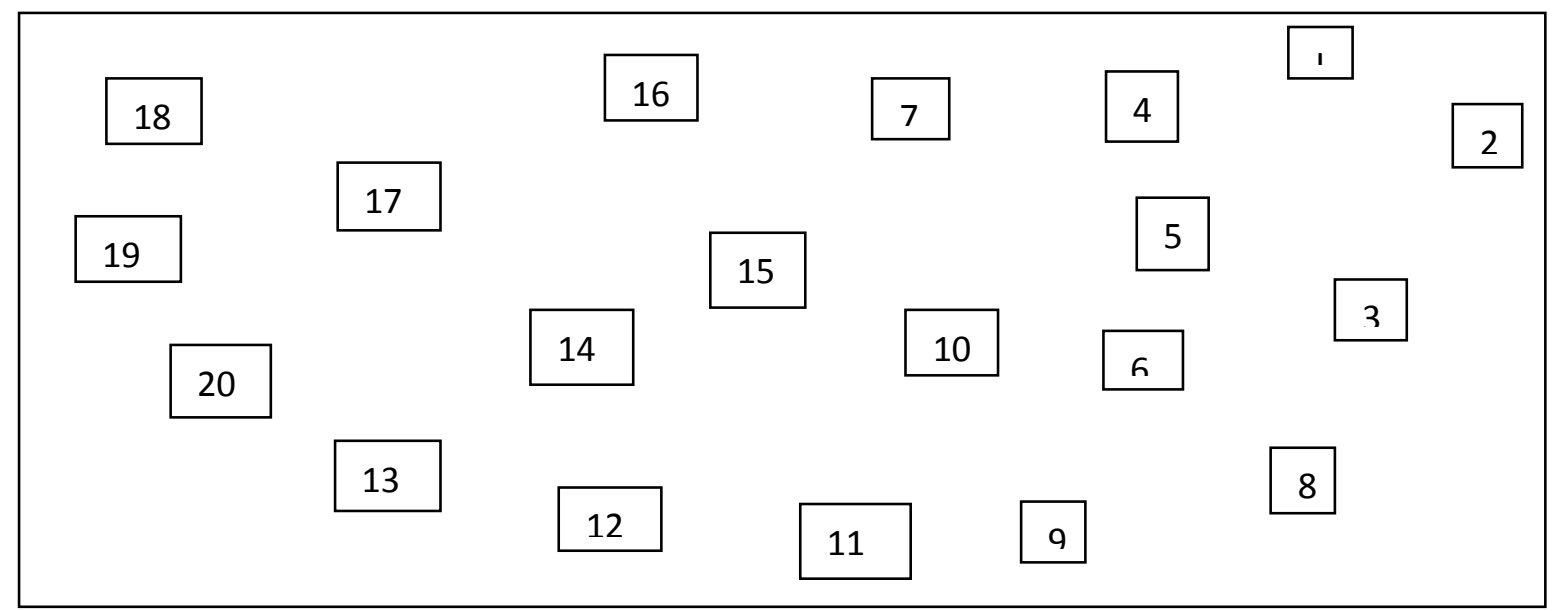

Keterangan:

Figure $2<$ Points on Graph>

1. Internet of things

2. Technopreneurship

3. Digital image processing

4. Information dan network security

5. Research Methods

6. Human dancomputer interaction

7. Socio-cultural science

8. Artificial intelegence

9. Automata language theory

10. Computer Network

11. Programming

12. Analysis design

13. Citizenship

14. Database management

15. English

16. Data structure

17. Mathematics

18. Calculus

19. Computer organitation

20. Linear algebra

The second step is to decide the side for connecting two knots which are connected, in other word the side shows of two the courses taken by the students in together.

The third step is to order the points in the graph at a decreasing degree then giving color to the highest point with the same color, so the point which is side along other points has different colors and so on until the last point (Niarma, Pramono dan Tajidun, 2018).

Based on the Welch Powell algorithm, the graph has chromatic number 8 , because of the number of color minimum uses as many 8 . There are 8 kinds of the condition in setting the course schedule in the Informatic Engineering study program in STIKOM Yos Sudarso so that the scheduling conflict does not happen. The same color shows the courses can be implemented at the same time. The different color shows the courses can not be scheduled at the same time. Tabel one shows 8 conditions scheduling can be taken at the same time. 


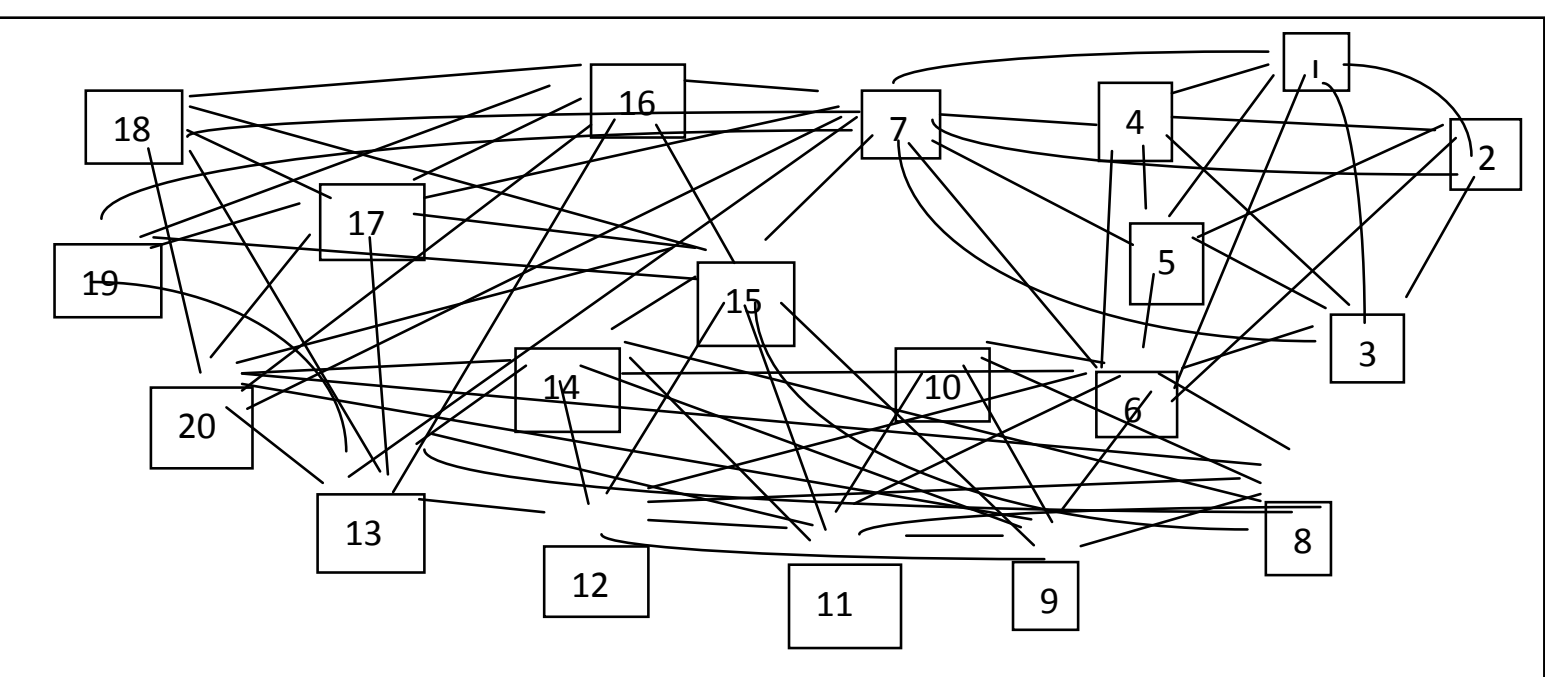

Figure 3 <The Course Graph Which is Taken in Even Semester>

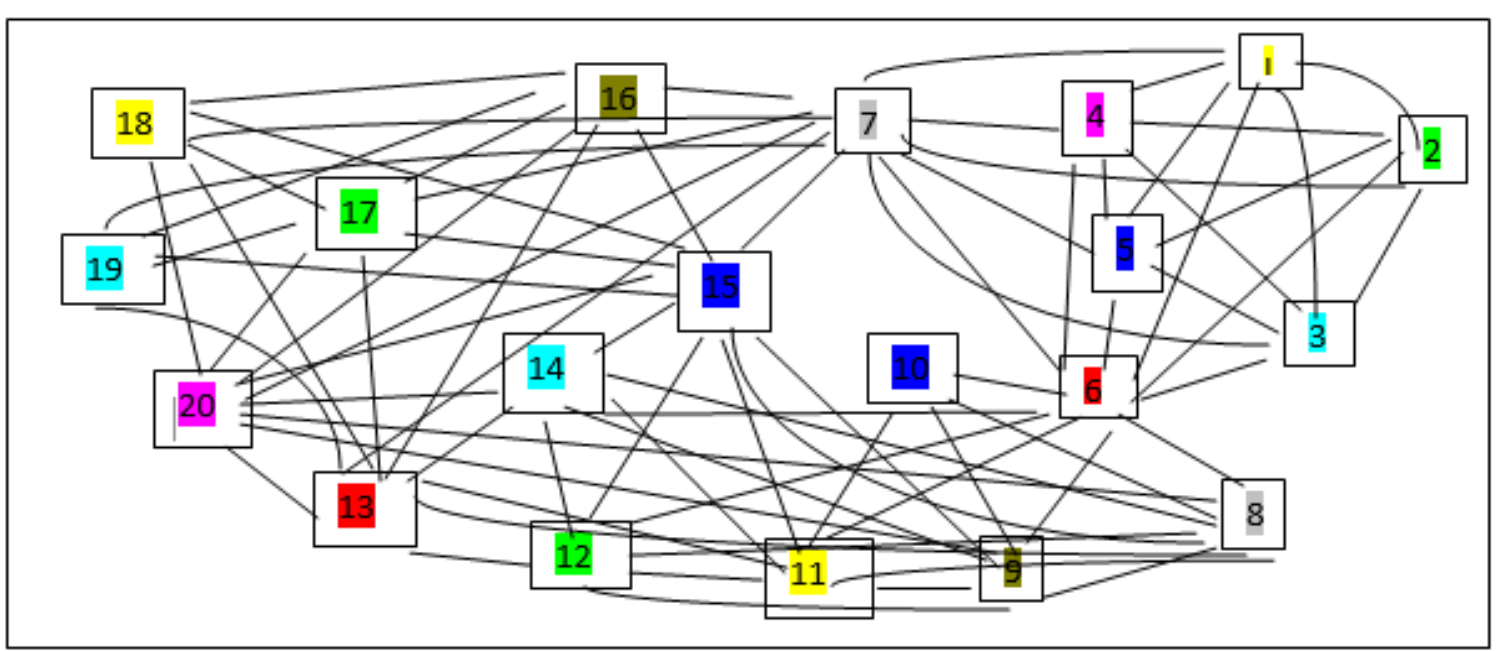

Figure $4<$ Graph Coloring of Courses Taken in the Even Semester $>$

Tabel $1<$ The Course Scheduling Condition in Informatics Engineering Even Semester>

\begin{tabular}{lc}
\hline Color & Courses \\
Yellow & Internet of things, Programming, Calculus \\
Green & Technopreneurship, Mathematics, Analysis Design \\
Light Blue & Digital Image Processing, Database Management, Computer Organitation \\
Purple & Information \& Network Security, Linear Algebra \\
Dark Blue & Research Methods, Computer Network, English \\
Red & Human\&Computer Interactionr, Citizenship \\
Grey & Artificial Intelegence, Socio-Cultural Science \\
Brown & Automata Language Theory, Data Structure \\
\hline
\end{tabular}

The first table is concluded that if the schedule of the Internet of things, Programming, and Calculus can be implemented at the same time with different rooms. Besides that, the courses schedule Technopreneurship, Mathematics, and Analysis data can be held at once but in different rooms and so on. From all the conditions which are produced, there is no conflict in Informatics Engineering STIKOM Yos Sudarso. 


\section{Conclusion}

Graph theory has an important role in order scheduling. One algorithm that is effective to be used is the Welch Powell algorithm for ordering to schedule conflict in Informatics Engineering STIKOM Yos Sudarso. The algorithm produces chromatic number 8 . It means using the Welch Powell algorithm has 8 conditions course scheduling which can be set so that the conflict does not happen. Therefore, it approves the algorithm that can be applied effectively and efficiently in organizing the course schedule in Informatics Engineering.

\section{Acknowledgments}

This research is funded by RISTEKDIKTI (Direktorat Riset dan Pengabdian Masyarakat Direktorat Jenderal Riset dan Pengembangan, Kementrian Riset Teknologi dan Pendidikan Tinggi).

\section{References}

Handayani, S., Ely, R., Paramita., M R.A. (2016). Penerapan Algoritma Welch Powell Dengan Pewarnaan Graph Pada Penjadwalan Mata Pelajaran SMA. Seminar Nasional Sistem Informasi Indonesia, 333338.

Jaya, Akram, Fathani, Hikmah \& Adniati. (2019). Perbandingan Algoritma Pewarnaan LDO, SDO, dan IDO pada Graf Pengaturan Lampu Lalu Lintas di Persimpangan Lima Kota Tua Ampenan. Eigen Mathematics Jurnal, 13-20.

Maryana. (2015). Pewarnaan Graf Pada Penyusunan Jadwal Perkuliahan di Politeknik AKAMIGAS Palembang. Jurnal Teknik PATRA Akademika, 30-33.

Niarma, Pramono and Tajidun. (2018). Aplikasi Penjadwalan Menggunakan Algoritma Welch Powell (Studi Kasus: SMA Muhammadiah Kendari). SemanTIK, 1-6.

S, Astuti. (2011). Penyusunan Jadwal Ujian Mata Kuliah Dengan Algoritma Pewarnaan Graf Welch Powell. Jurnal Dian, 68-74. 